ple. Voronoff became persuaded that a successful xenograft must in general come from a closely related species, not for example from ruminants, and many monkeys were emasculated in the interests of this theory. In the United States prison doctors joined in the game, and were able to go one better: Dr Stanley of San Quentin gaol implanted 30 of his charges with testicles from executed felons and later reported highly satisfactory results from 643 assorted gland transplant operations. All these grafts must of course have been rapidly rejected.

Worse yet was Brinkley, the Kansas quack - unencumbered by any genuine medical qualifications. He chose the goat (an odourless variety), as a species traditionally associated with sexual exuberance, to turn the prematurely enfeebled into satyrs. He and his wife introduced what amounted to a conveyer-belt system of surgery. As a decorative touch, he even injected mercurochrome into the severed end of the vas deferens, to impart a rich colour to the urine and impress the patient. Brinkley owned the hotels that served as convalescent centres, and he set up a radio station to advertise his operation (which was offered in standard and de luxe versions), as well as a range of pharmaceutical products. He became extremely rich and popular, and fought a close-run election for State Governor before his luck ran out.

Meanwhile in Paris, Voronoff had married into money on a grand scale and had become a social lion. His second marriage was to a surmised daughter of King Carol of Roumania and the infamous Madame Lupescu. Hamilton makes the point that in the aftermath of the Great War, in which the best had perished and the breeding stock of the upper classes been seriously depleted, and when indeed eugenic theories were widely touted, European society was peculiarly receptive to promises of increased virility and fertility. Voronoff, who was a tireless and prodigiously talented self-publicist, took full advantage of these preoccupations. $\mathrm{He}$ also extended his activities to the breeding of sheep, in which he saw great pecuniary promise. The results of Lamarckian (or Lysenkoist) experiments, conducted in Algeria, on the effects of testicular grafts on the performance of rams and the woolyield of their offspring, were proclaimed a triumph; the British Thoroughbred Breeders Association took fright and announced that grafted racehorses would be struck from the stud-book.

Then Voronoff fell like Lucifer. He was brought down largely through the resolute scepticism of a number of French and English vets, who knew an uncontrolled experiment when they saw one - a circumstance shaming to the medical establishment, which had vacillated feebly throughout Voronoff's years of ascenden- cy. The most tenacious and clear-sighted was Henri Velu, who ran a sheepbreeding station in Morocco, and in the end he outfaced Voronoff and his many powerful supporters. Moreover testosterone had shortly before been isolated by (as Hamilton calls him) a Dr Funk. This was none other than Casimir Funk, the man who gave us the word vitamin and was said to have enraged the Mussolini regime when, learning that Italian prisoners taken in the Abyssinian War were being castrated by their captors, he attempted to negotiate a consignment of the resulting material. Injections of testosterone were found ineffective in the treatment of sexual decline. So began Voronoff's years of eclipse.

David Hamilton has penetrated the shell of Voronoff's formidable public persona, and come to like the man within, self-seeking poseur though he quite evidently was. Tout comprendre, as they say, est tout pardonner. The book is dedicated to Serge-Samuel Voronoff.

Walter Gratzer is in the Medical Research Coun cil Cell Biophysics Unit, Kings College London (KQC), 26-29 Drury Lane, London WC2B $5 R L, U K$.

\section{Medical matters}

\section{Lewis Thomas}

The Oxford Companion to Medicine, Vols I and II. Edited by John Walton, Paul B. Beeson and Ronald Bodley Scott. Oxford University Press: 1986. Pp.1,524. £55, \$95.

I PICKED up the first of these two volumes at 11 o'clock one evening, and could not lay it down until 11:05. This sounds like the start of an uncordial review, but it means only to say quickly that this new encyclopaedia is not made for steady latenight reading. But for leafing through at random, in spare moments, with nothing particular in mind, The Oxford Companion to Medicine contains some unexpected pleasures. All in all, it is an earnest but good-natured piece of work, 1,500 or so pages of what seem rather randomly selected topics, some of them just a few lines of definition, others lengthy essays on one or another aspect of medicine, health, disease, medical practice, and quite a lot on the organization and economics of medicine.

Among the surprises, for me anyway, is a long essay on Doctors as Patients ("doctors have a healthy skepticism about the efficacy of the art they practice"), Doctors as Athletes, Doctors as Missionaries, Doctors in Other Walks of Life (the arts, the law, philosophy, the Church, crime).

Although the editors state in their preface that they hope for a readership made up of intelligent laymen as well as physi- cians, nurses and other health care professionals, including students, my guess is that the volumes will be most appealing to people who simply like browsing, whatever their background. If, as the editors hope, there is "a plastic surgeon wishing to learn more about the role and responsibilities of a psychiatrist", he will find plenty to read, eleven pages on Psychiatry and another ten on Psychology in Relation to Medicine. The psychiatrist, for his part, will find five pages on Plastic and Maxillofacial Surgery, directly following a short paragraph explaining Plaster of Paris. And any practitioner or layman wanting to know more about Death, Dying and the Hospice Movement, or about Government and Medicine in the UK (and also in the USA), or about Community Medicine, or Dentistry, or Cardiothoracic Surgery, or Medical Museums, or the Medical Services of the Royal Navy, or Women in Medicine, will find pages of essays on these and other broad topics. But, along the way, the casual reader will run into the Opening Snap ("associated with mitral valve opening at the beginning of diastole"), Suffocation ("the interruption of breathing by deprivation of air"), Weakness ("lack of strength, feebleness, ill health"), Neurotoxin ("any agent which is toxic to nervous tissue") and a lot of other items not needing even the one or two lines given them.

Whatever the intended readership, one thing The Oxford Companion to Medicine is not: it is not, despite the title, any kind of guide for do-it-yourself-at-home medicine, and the lay person who shells out $£ 55$ with this in mind will be disappointed. There is, to my own disappointment, not even much material to enlighten the layman on what to stay away from, in the light of those endless shelves of paperbacks in every airport lounge providing promises by immunity-stimulating diets, magical exercises, trace metals, vitamins, rejuvenating lotions, even books on how to think straight. To be sure, if you go looking you can find some of this, under Fringe Medicine, Cults and Quackery. In the absence of an index (which these two volumes could surely use) you have to be lucky and browsing through the F's to find it, and even so this section deals mostly with the health frauds of the nineteenth century and not enough with the more outrageous follies of this one.

In short, this is a curious, rather unpredictable, almost quirky encyclopaedia. Some will find it useful in spots, interesting for some of the essays. I'm glad to possess it, but I'm afraid that long before my pages became thumbworn my thumbs would be pageworn.

Lewis Thomas is Professor Emeritus at the Memorial Sloan-Kettering Cancer Center, 1275 York Avenue, New York, New York 10021, USA, and University Professor at the State University of New York, Stony Brook. 